\title{
Hybrid insolation forcing of Pliocene monsoon dynamics in West Africa
}

\author{
Rony R. Kuechler, Lydie M. Dupont, and Enno Schefuß \\ MARUM - Center for Marine Environmental Sciences, University of Bremen, Leobener Str. 8, 28359 Bremen, Germany \\ Correspondence: Lydie Dupont (ldupont@marum.de)
}

Received: 30 May 2017 - Discussion started: 20 June 2017

Revised: 28 November 2017 - Accepted: 29 November 2017 - Published: 16 January 2018

\begin{abstract}
The Pliocene is regarded as a potential analogue for future climate with conditions generally warmer-thantoday and higher-than-preindustrial atmospheric $\mathrm{CO}_{2}$ levels. Here we present the first orbitally resolved records of continental hydrology and vegetation changes from West Africa for two Pliocene time intervals (5.0-4.6 Ma, 3.6-3.0 Ma), which we compare with records from the last glacial cycle (Kuechler et al., 2013). Our results indicate that changes in local insolation alone are insufficient to explain the full degree of hydrologic variations. Generally two modes of interacting insolation forcings are observed: during eccentricity maxima, when precession was strong, the West African monsoon was driven by summer insolation; during eccentricity minima, when precession-driven variations in local insolation were minimal, obliquity-driven changes in the summer latitudinal insolation gradient became dominant. This hybrid monsoonal forcing concept explains orbitally controlled tropical climate changes, incorporating the forcing mechanism of latitudinal gradients for the Pliocene, which probably increased in importance during subsequent Northern Hemisphere glaciations.
\end{abstract}

\section{Introduction}

The hydrologic cycle is of vital importance for the global climate system, owing to its function in regulating the heat and moisture balance (Lindzen, 1990, 1994). This is mainly achieved through the atmospheric and ocean circulation, which tend to equalize the differences in solar heating between low and high latitudes. The importance of this heat redistribution is illustrated by the fact that around $50 \%$ of the annual energy budget of high latitudes originates from lower latitudes (Peixoto and Oort, 1992), peaking in winter, when polar night conditions prevail at high latitudes (Davis and Brewer, 2011). In this way, atmospheric water vapour acts as the dominant greenhouse gas, exerting an important feedback on global warming (e.g. Held and Soden, 2000). Thus a good understanding of the dynamics of the hydrological cycle is crucial. However, focusing on the instrumental record only would limit the state of our knowledge (Brohan et al., 2006). To assess the dynamics of a changing climate, palaeoclimate studies provide means to investigate long-term developments of the monsoon (Mohtadi et al., 2016).

Monsoon systems are the most prominent parts of the global hydrological cycle. Monsoon variability on orbital timescales is mainly attributed to variations in low-latitude summer insolation, which is dominated by 19 and $23 \mathrm{kyr}$ periodicities of the precession cycle (e.g. Kutzbach, 1981; Rossignol-Strick, 1983; Tiedemann et al., 1994; Larrasoaña et al., 2013; Mohtadi et al., 2016). Consequently, maximum insolation intensities are expected to increase monsoon circulation and thus rainfall, comparable to modern seasonal variations. Recent sensitivity studies show that the effect of precession on tropical climate is far stronger than that of obliquity (Bosmans et al., 2015a). Nevertheless, obliquity (41 kyr) cycles have also been detected in sequences of Mediterranean sapropels (Lourens et al., 1996), which formation depends on monsoonal freshwater discharge from Africa (Rossignol-Strick, 1983; Colleoni et al., 2012; Larrasoaña et al., 2013). Equally, dust flux rates at Ocean Drilling Program (ODP) Site 659 (Tiedemann et al., 1994) and pollen flux rates at ODP Site 658 (Dupont et al., 1989) show obliquity cycles in records of tropical Africa, which are difficult to explain, since obliquity has a negligible effect on lowlatitude insolation (Laskar, 1990). 
A plausible mechanism that incorporates the obliquity signal and the climatic linkage between low and high latitudes is found in the latitudinal insolation gradient (LIG; Davis and Brewer, 2009). This intra-hemispheric insolation gradient leads to differential heating between the cold polar regions and the hot tropics and creates the latitudinal temperature/pressure gradient, which ultimately controls the poleward heat and moisture transport, a mechanism that has been invoked in the so-called "gradient hypothesis" by Raymo and Nisancioglu (2003) to explain the strong obliquity rhythm of glacial-interglacial cycles between 0.8 and 3.0 Ma (the " $41 \mathrm{kyr}$ world"). Another gradient hypothesis is favoured by Bosmans et al. (2015b), who suggest that the inter-hemispheric insolation gradient drives winds and associated cross-equatorial moisture transport deep into the African continent linked with an intensification of the Hadley cell during winter (Reichart, 1997). The same mechanism has been invoked by Leuschner and Sirocko (2003) defining the Indian summer monsoon index. The concept of insolation gradients is supported by recent climate model studies (Mantsis et al., 2014) simulating an enhanced mid-latitude eddy circulation (which is important for the heat and moisture transport from low to high latitudes) in response to low obliquity (resulting in a strong LIG during summer), and a concomitant shift of the poleward boundaries of the tropical rain belt towards the Equator. In addition, weakening of the inter-hemispheric gradient leads to diminished cross-equatorial heat transport and a weaker Hadley circulation during winter (Reichart, 1997; Bosmans et al., 2015a). Further model simulations corroborate the importance of an obliquity-induced insolation gradient forcing for West African monsoon variability (Rachmayani et al., 2016).

Both gradient hypotheses stay in contrast to the traditional view, in which the obliquity signal in the tropics is linked to changes in the extent of glaciations. Northern Hemisphere ice sheets and sea ice would affect the monsoon through the impact on the atmospheric circulation and moisture advection (Tiedemann et al., 1994; DeMenocal, 1995; Mohtadi et al., 2016). Using Pliocene records (between 5 and $\sim 3 \mathrm{Ma}$ ) that register palaeoclimate prior to the intensification of the Northern Hemisphere glaciation, we can test if the monsoon system responds to obliquity independently of Northern Hemisphere ice growth and decay.

Another good reason to study the warmer-than-today climate of the Pliocene is that many boundary conditions are similar to today (Dowsett et al., 2013; Haywood et al., 2013). This last warm period of the geological record is often referred to as future analogue. For the assessment of Pliocene climate conditions, focus has been on sea surface (Dowsett et al., 2013) and continental temperatures (Salzmann et al., 2013). Global mean annual temperatures were more than $3{ }^{\circ} \mathrm{C}$ warmer and sea level was about $22 \pm 10 \mathrm{~m}$ higher than at present (Dowsett et al., 2013; Haywood et al., 2013). However, data-model mismatches have been detected for terrestrial temperature estimates in the tropics likely due to limited

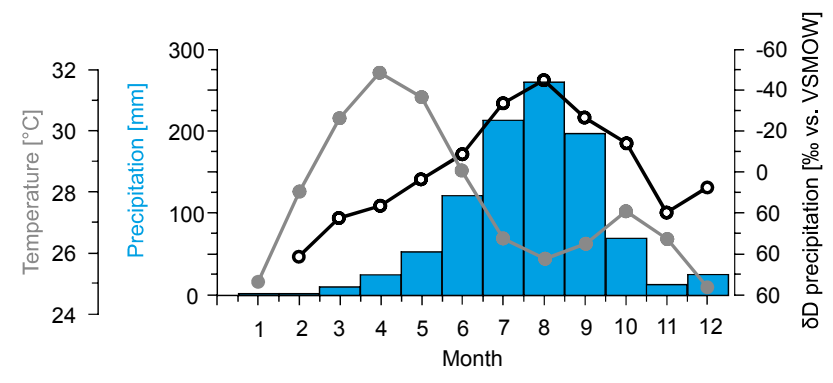

Figure 1. Monthly precipitation (blue), $\delta \mathrm{D}$ of precipitation (black relative to Vienna Standard Mean Ocean Water) and temperature (grey) at Bamako (Mali; 12 $41^{\prime} 24^{\prime \prime} \mathrm{N}, 7^{\circ} 59^{\prime} 24^{\prime \prime} \mathrm{W}$; $381 \mathrm{~m}$ ) exemplifying the amount effect (Dansgaard, 1964) in West African hydrology (IAEA/WMO, 2014). This relationship is shown for monthly means, but also holds true on an annual basis (Rozanski et al., 1993).

proxy data (Salzmann et al., 2013). Moreover, a model intercomparison revealed inconsistencies in tropical precipitation estimates (Haywood et al., 2013), indicating that more data on tropical hydrology are needed.

Hydrogen isotopes (deuterium) of plant leaf waxes $\left(\delta \mathrm{D}_{\text {wax }}\right)$ provide a proxy for palaeohydrologic variations (Fig. 1) related to the isotopic composition of precipitation $\left(\delta \mathrm{D}_{\text {rain }}\right.$; Sachse et al., 2012). In tropical regions, $\delta \mathrm{D}_{\text {rain }}$ is negatively correlated to precipitation amounts (Dansgaard, 1964; Rozanski et al., 1993; Risi et al., 2008), whereas $\delta D_{\text {wax }}$ also incorporates secondary effects of evapotranspiration, plant physiology, and photosynthetic pathway (Sachse et al., 2012). In areas with $C_{4}$ grasses, the stable carbon isotopic compositions of the same compounds $\left(\delta^{13} \mathrm{C}_{\mathrm{wax}}\right)$ provide additional information about vegetation changes and can be used to differentiate between contributions from grassy $\left(\mathrm{C}_{4}\right)$ and woody $\left(\mathrm{C}_{3}\right)$ vegetation (e.g. Vogts et al., 2009).

Our study focusses on ODP Site 659, situated offshore of West Africa and centred beneath the main wind trajectories (Fig. 2). Its dust record provides evidence for the persistence of orbital arid-humid cycles during the last $5 \mathrm{Myr}$ (Tiedemann et al., 1994). Coupled $\delta \mathrm{D}_{\text {wax }}$ and $\delta^{13} \mathrm{C}_{\mathrm{wax}}$ analyses from this site for the last glacial cycle have demonstrated their ability to record shifts in West African hydrology and vegetation (Kuechler et al., 2013). However, $\delta D_{\text {wax }}$ studies from West Africa covering the Pliocene have not yet been published. Here we provide orbitally resolved $\delta \mathrm{D}_{\text {wax }}$ and $\delta^{13} \mathrm{C}_{\mathrm{wax}}$ records for two time intervals (5.0-4.6 Ma and 3.6-3.0 Ma) to evaluate hydrologic changes in Pliocene West Africa. In addition to the well-established precession forcing, we discuss further insolation mechanisms to explain the long-term evolution of the West African hydrologic cycle. 


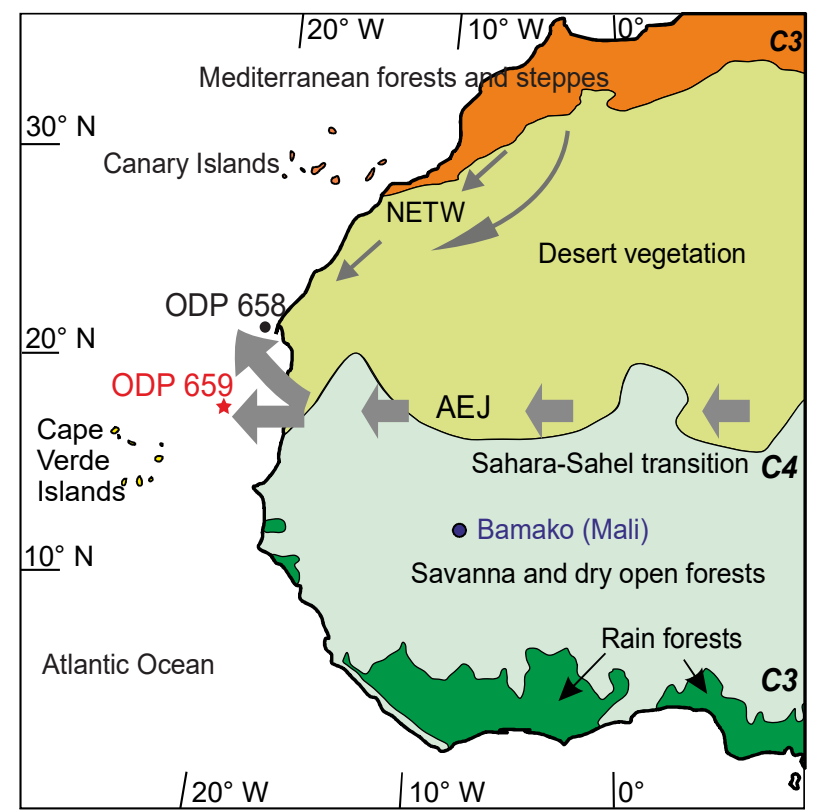

Figure 2. Location of Ocean Drilling Program (ODP) Sites 659 (star; $18^{\circ} 05^{\prime} \mathrm{N}, 21^{\circ} 02^{\prime} \mathrm{W} ; 3070 \mathrm{~m}$ water depth) and 658 (dot; $20^{\circ} 45^{\prime} \mathrm{N}, 18^{\circ} 35^{\prime} \mathrm{W} ; 2263 \mathrm{~m}$ water depth) offshore of West Africa (Ruddiman et al., 1987) and the location of Bamako in Mali. Main vegetation zones (dashed lines; simplified after White, 1983), dominant photosynthetic pathways (right), atmospheric trajectories (arrows). The thickness of the arrows marks the different altitudes of the African Easterly Jet (AEJ; > $3000 \mathrm{~m}$ ) and the north-east trade winds (NETW; < $1000 \mathrm{~m}$ ).

\section{Modern climate and vegetation}

The amount and distribution of precipitation in West Africa is a function of latitude (Nicholson, 2009; Fig. 3). Tropical rainfall is tightly linked to atmospheric dynamics at higher altitudes, involving the African Easterly Jet (AEJ) and the Tropical Easterly Jet (Nicholson, 2009). Highest precipitation amounts are found in the equatorial regions, which are marked by a double rainfall maximum, occurring during the transition seasons, which is mostly attributed to the latitudinal migration of the Intertropical Convergence Zone. Further north a single rainfall maximum occurs during summer (July/August), when a low-pressure system is formed over the Sahara due to stronger heating of the northern African continent relative to the adjacent ocean. This low-pressure system is situated between the NE trade winds and the moist "SW monsoon". Precipitation during the wet season in Sahara and Sahel moderates the surface temperatures, thus enhancing the temperature contrast to the hyperarid Sahara in the north, which strengthens the AEJ during its northward displacement after rainfall (Nicholson and Grist, 2003). Precipitation in the temperate regions of North Africa is influenced by the mid-latitude westerlies falling mainly during the winter season. The Sahara separates the summer and winter precipitation regimes and thus, exhibits a complex pattern. Much of the rainfall in the desert occurs during the transition seasons and has an extra-tropical origin related to the mid-latitude westerlies interacting with the tropical easterlies (Nicholson, 1981, 2000).

The modern vegetation distribution and composition in West Africa (White, 1983) reflects the latitudinal migration of the tropical rain belt (Fig. 3). Close to the Equator, high precipitation rates lead to dense vegetation cover, consisting of tropical rain forests and woodlands (mostly $\mathrm{C}_{3}$ ). Further to the north, towards the Sahara, increasingly open grasslands (mostly $\mathrm{C}_{4}$ ) occur as rainfall decreases and wet season length shortens. North of the Sahara, the Mediterranean vegetation is composed of scrublands, steppes, and forests, which consist exclusively of $\mathrm{C}_{3}$ plants.

\section{Material and methods}

ODP Site 659 is located on top of the submarine Cape Verde Plateau at $3070 \mathrm{~m}$ water depth (Fig. 2; Ruddiman et al., 1987). The siliciclastic fraction is considered to be of purely aeolian origin due to low carbonate concentrations in the dust composition and its distal location on a submarine rise excluding fluvial input (Tiedemann et al., 1994). Two Pliocene age models have been established, one based on variations in dust accumulation (Tiedemann et al., 1994) and the other based on stable oxygen isotopes $\left(\delta^{18} \mathrm{O}\right)$ of benthic foraminifers (Clemens, 1999).

Stable isotope analyses of hydrogen $(\delta \mathrm{D})$ and carbon $\left(\delta^{13} \mathrm{C}\right)$ were carried out on 230 samples of cores 10,11 , 14 , and 15 of Hole A. The analysed three Pliocene intervals range from 3.00 to $3.27,3.31$ to 3.62 , and 4.63 to $5.00 \mathrm{Ma}$ ) with an average temporal resolution of $\sim 4 \mathrm{kyr}$, comparable to the dust record of the same site (Tiedemann, 1991; Tiedemann et al., 1994). A sampling gap between 3.31$3.27 \mathrm{Ma}$ is related to a core break between cores 10 and 11 of Hole A. A detailed description of methods, including lipid extraction, quantification and stable isotope analyses, is given in Kuechler et al. (2013). $\delta$ D values are reported relative to Vienna Standard Mean Ocean Water (VSMOW). An external $n$ alkane standard yielded a precision $(1 \sigma)$ and accuracy of $2 \%$, and squalane as internal standard yielded values of 2 and $1 \%$, respectively. The mean precision $(1 \sigma)$ of replicates for the $n-\mathrm{C}_{29-33}$ alkanes is $2 \%$ o. $\delta^{13} \mathrm{C}$ values are reported relative to the Vienna Pee Dee Belemnite (VPDB) standard. The external standard yielded a precision $(1 \sigma)$ of $0.3 \%$ and an accuracy of $<0.1 \%$. The values for internal standard are 0.2 and $0.3 \%$, respectively. Replicates yielded a mean precision $(1 \sigma)$ for the $n-\mathrm{C}_{29-33}$ alkanes of $0.2 \%$. Data sets are stored online at PANGAEA (https://doi.org/10.1594/PANGAEA.875694; Küchler et al., 2017).

Statistical analysis has been carried out using the software package PAST 3.0 (Hammer et al., 2001). To calcu- 


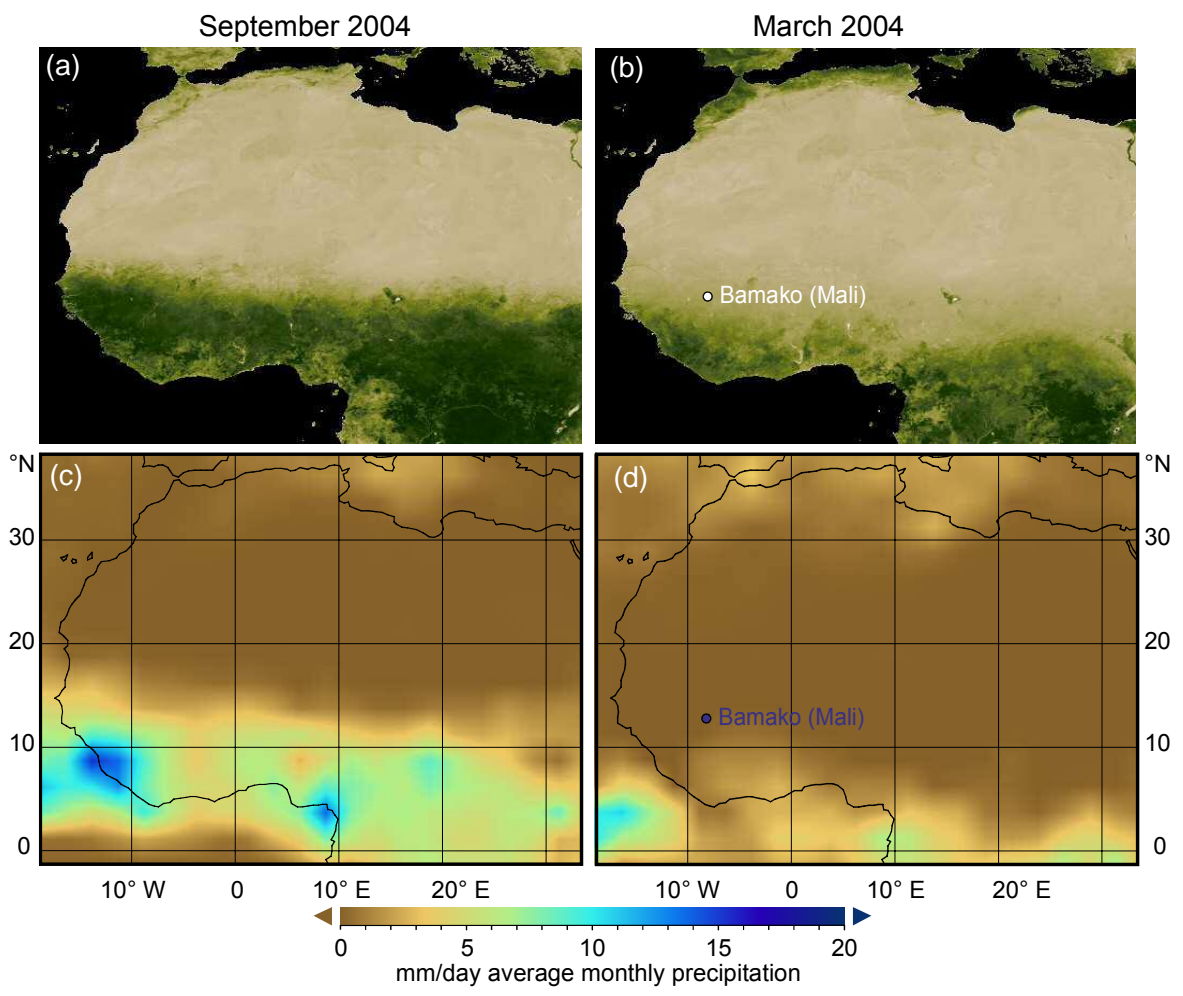

Figure 3. Seasonal extremes in vegetation (a, b, NDVI, normalized difference vegetation index available at www.earthobservatory.nasa.gov) and rainfall (c, d, precipitation in mm per day available at http://www.cdc.noaa.gov/) of northern and West Africa in September 2004 (a, c) vs. March 2004 (b, d).

late correlation coefficients data sets have been re-sampled at steps of $4 \mathrm{kyr}$ (close to the original average temporal resolution). In order to illustrate the temporal evolution of the dust and $\delta \mathrm{D}_{\text {wax }}$ records, we applied continuous wavelet transform (Morlet) after Torrence and Compo (1998). For this spectral analysis, the Pliocene data sets were linearly interpolated to an even spacing of $5 \mathrm{kyr}$, and the Pleistocene data set to $3 \mathrm{kyr}$. Significance $(p=0.05)$ is tested after a chi-squared test with the null hypothesis of a white noise model.

\section{Results}

Plant-wax-derived long-chain $n$ alkane concentrations from ODP Site 659 (Fig. 4) mostly vary between 0.01 and $0.80 \mathrm{\mu g} \mathrm{g}^{-1}$ dry sediment and are correlated (Table 1) with the dust record (Tiedemann, 1991). Carbon preference index values mostly exceed 3 , indicating terrestrial plant contributions (Eglinton and Hamilton, 1967).

Stable carbon isotope compositions of $n$ alkanes fluctuated between -27.3 and $-24.7 \%$, -26.5 , and $-24.4 \%$, and between -26.1 and $-23.3 \%$ for the $n-\mathrm{C}_{29}, n-\mathrm{C}_{31}$, and $n-\mathrm{C}_{33}$ alkanes, respectively. A trend to more enriched values towards the present started at 3.2 Ma. Isotopic signatures of the major homologues significantly correlate (Table 1). Therefore, we focus on the $n-\mathrm{C}_{31}$ alkane as the most abundant compound, attributed to the prevailing $\mathrm{C}_{4}$ grass input (Vogts et al., 2009). Spectral analysis (wavelet analysis) indicates that the variability in the isotope record is not stable (Fig. 5). During the periods between 4.7 and $4.65 \mathrm{Ma}$ and between 3.1 and 3.0 Ma both significant precession and obliquity variability are found in the $\delta^{13} \mathrm{C}_{31}$ record. Additional precession variability is found between 3.48 and $3.38 \mathrm{Ma}$. These periods are characterized by large eccentricity and thus large precession cycle amplitudes. On the other hand, this type of orbital variability breaks down during periods with low precessional variability $(4.917-4.775,3.520-3.475,3.405-3.360$, and 3.236-3.190 Ma; see boxes in Fig. 5).

Hydrogen isotope compositions of $n$ alkanes fluctuate between -160 and $-124 \%$ o, -171 and $-133 \%$, and between -177 and $-127 \%$ or the $n-\mathrm{C}_{29}, n-\mathrm{C}_{31}$, and $n-\mathrm{C}_{33}$ alkanes, respectively. Again, isotopic signatures of the homologues significantly correlate (Table 1 ) and we thus focus on $\delta D_{\text {wax }}$ values of the $n-\mathrm{C}_{31}$ alkanes, too. Pliocene $\delta \mathrm{D}_{31}$ values range from -171 to $-133 \%$ (Fig. 4) and show alternating arid and humid conditions in which $\delta \mathrm{D}_{31}$ maxima (less negative) indicate aridity corresponding with the dust maxima (Tiedemann, 1991). Spectral analysis indicates some precessional variability around $4.7 \mathrm{Ma}$, between 3.55 and $3.52,3.35$ and 3.31, 3.15 and 3.19, and between 3.04 and 3.0 Ma (Fig. 5). 
Table 1. Correlation coefficients $(r)$ and $(p)$ for plant-wax-specific stable isotopes $\left(\delta \mathrm{D}, \delta^{13} \mathrm{C}\right)$, long-chain $n$ alkane $\left(n-\mathrm{C}_{x}\right)$ and dust percentages at ODP Site 659.

\begin{tabular}{|c|c|c|c|c|c|c|c|c|c|}
\hline & $n-\mathrm{C}_{x}$ & LGC & $p$ & mPWP & $p$ & pre-mPWP & $p$ & EP & $p$ \\
\hline \multirow[t]{3}{*}{$\delta \mathrm{D}$} & $29 / 31$ & 0.80 & $<0.01$ & 0.85 & $<0.01$ & 0.70 & $<0.01$ & 0.70 & $<0.01$ \\
\hline & $31 / 33$ & 0.74 & $<0.01$ & 0.83 & $<0.01$ & 0.58 & $<0.01$ & 0.63 & $<0.01$ \\
\hline & $29 / 33$ & 0.73 & $<0.01$ & 0.79 & $<0.01$ & 0.52 & $<0.01$ & 0.56 & $<0.01$ \\
\hline \multirow[t]{3}{*}{$\delta^{13} \mathrm{C}$} & $29 / 31$ & 0.86 & $<0.01$ & 0.87 & $<0.01$ & 0.82 & $<0.01$ & 0.60 & $<0.01$ \\
\hline & $31 / 33$ & 0.78 & $<0.01$ & 0.70 & $<0.01$ & 0.64 & $<0.01$ & 0.51 & $<0.01$ \\
\hline & $29 / 33$ & 0.62 & $<0.01$ & 0.66 & $<0.01$ & 0.73 & $<0.01$ & 0.41 & $<0.01$ \\
\hline \multirow[t]{3}{*}{$\delta$ D vs. $\delta^{13} \mathrm{C}$} & 29 & -0.08 & 0.67 & 0.42 & $<0.01$ & 0.20 & 0.08 & 0.12 & 0.24 \\
\hline & 31 & -0.55 & $<0.01$ & 0.36 & $<0.01$ & -0.04 & 0.76 & -0.23 & 0.03 \\
\hline & 33 & -0.70 & $<0.01$ & 0.01 & 0.91 & -0.10 & 0.38 & 0.05 & 0.61 \\
\hline \multicolumn{2}{|c|}{$\delta \mathrm{D}_{31}$ vs. dust $\%$} & 0.34 & 0.02 & 0.41 & $<0.01$ & 0.21 & 0.06 & 0.23 & 0.02 \\
\hline \multicolumn{2}{|c|}{$n$-C $27-35$ vs. dust $\%$} & 0.36 & 0.02 & 0.48 & $<0.01$ & 0.16 & 0.16 & 0.70 & $<0.01$ \\
\hline
\end{tabular}

For statistical analyses (PAST 3.0; Hammer et al., 2001), the late Pliocene or Piacenzian interval was split into two periods corresponding to the mid-Piacenzian Warm Period (mPWP; 3.273-3.007 Ma) and a preceding one (pre-mPWP; 3.616-3.309 Ma) separated by a stratigraphic gap of $\sim 36 \mathrm{kyr}$ in the sedimentary record. The early Pliocene or Zanclean interval (EP) ranges from 4.997 to 4.625 Ma. Data sets were re-sampled at evenly spaced $4 \mathrm{kyr}$, which is close to the original average temporal resolution. Values for the last glacial cycle (LGC; last $130 \mathrm{kyr}$ after Kuechler et al., 2013) are given for comparison. Most $r$ values exhibit $p<0.01$ (in bold); less significant values are denoted in italics.

(a)

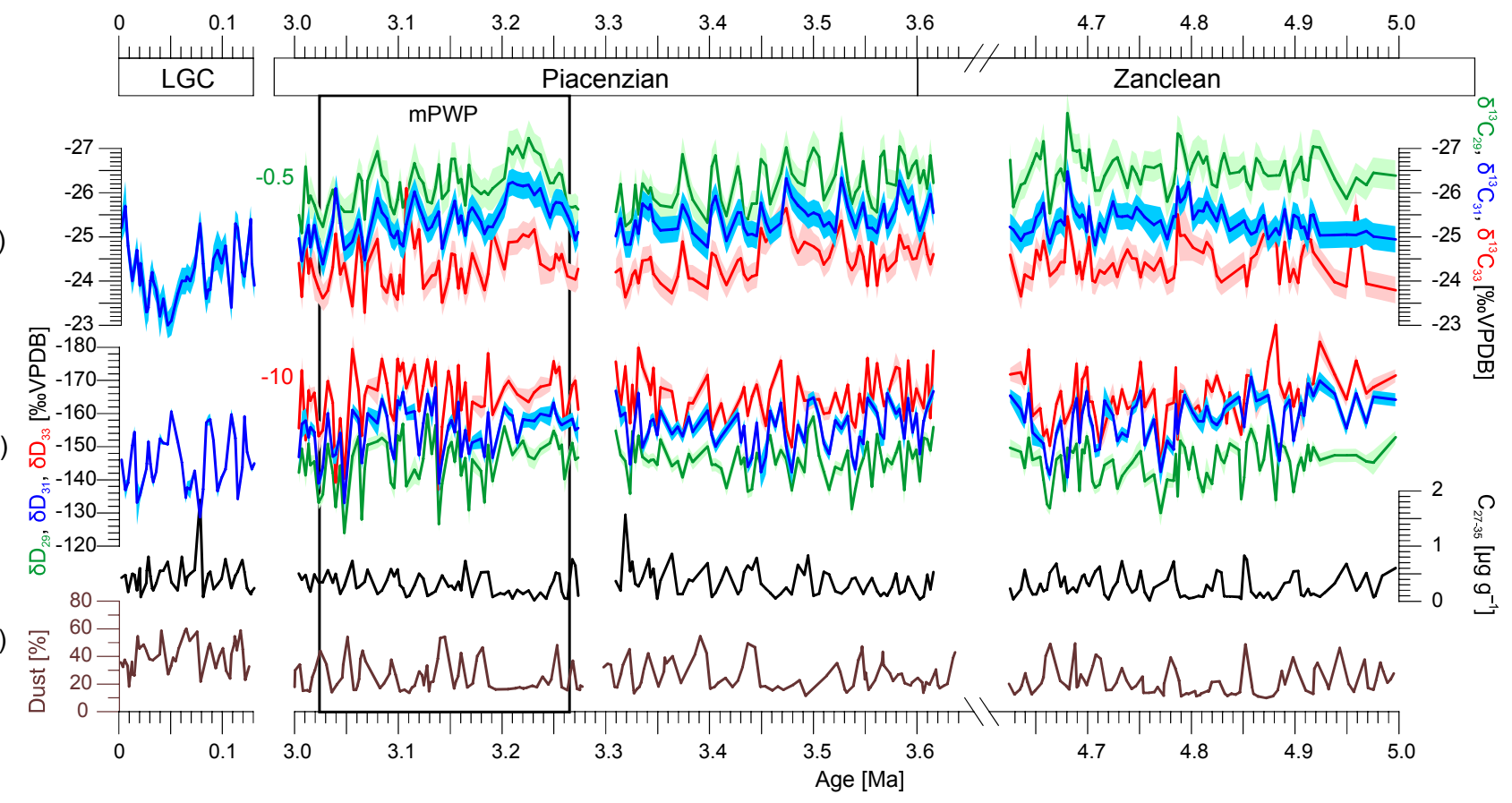

Figure 4. Results. (a-c) Stable carbon $\left(\delta^{13} \mathrm{C}\right)$ and hydrogen $(\delta \mathrm{D})$ isotope compositions of $\mathrm{C}_{29}-\mathrm{C}_{33} n$ alkanes in per mil vs. Vienna Pee Dee Belemnite (VPDB) and Vienna Standard Mean Ocean Water (VSMOW), respectively; $n$ alkane $\mathrm{C}_{27}-\mathrm{C}_{35}$ concentrations in microgram per gram dry sediment, and dust percentage after Tiedemann (1991) against time in millions of years (Ma). Age model after Clemens (1999). For visibility, $\delta^{13} \mathrm{C}_{29}$ values (green) are shifted minus $0.5 \%$ and $\delta \mathrm{D}_{33}$ values (red) minus $10 \%$. Results of the $\mathrm{C}_{31} n$ alkane for the last glacial cycle (LGC) from Kuechler et al. (2013) are plotted to the left for comparison. mPWP: mid-Piacenzian Warm Period. 


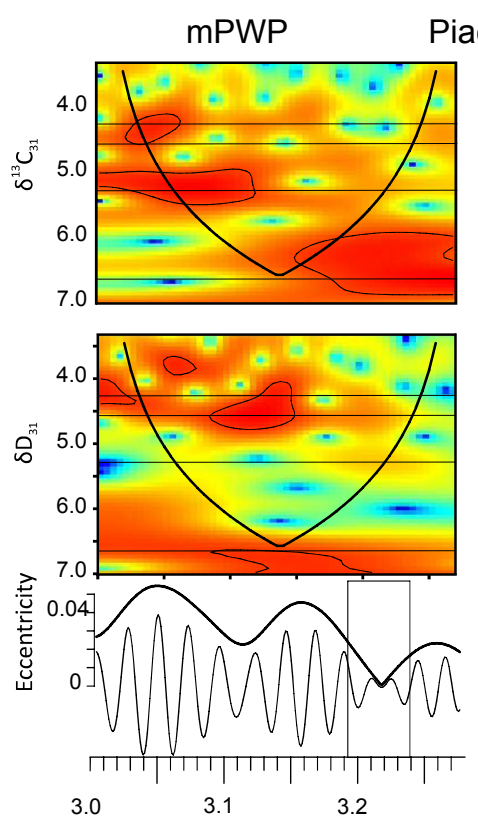

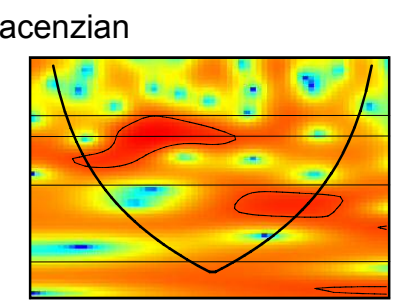
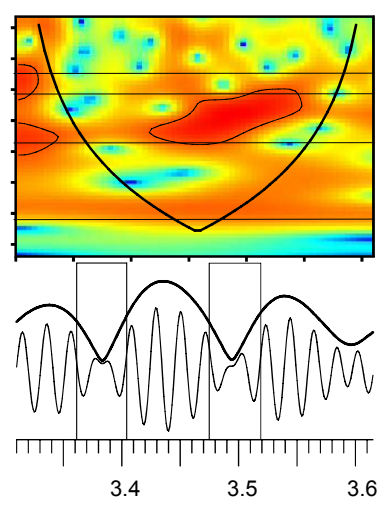
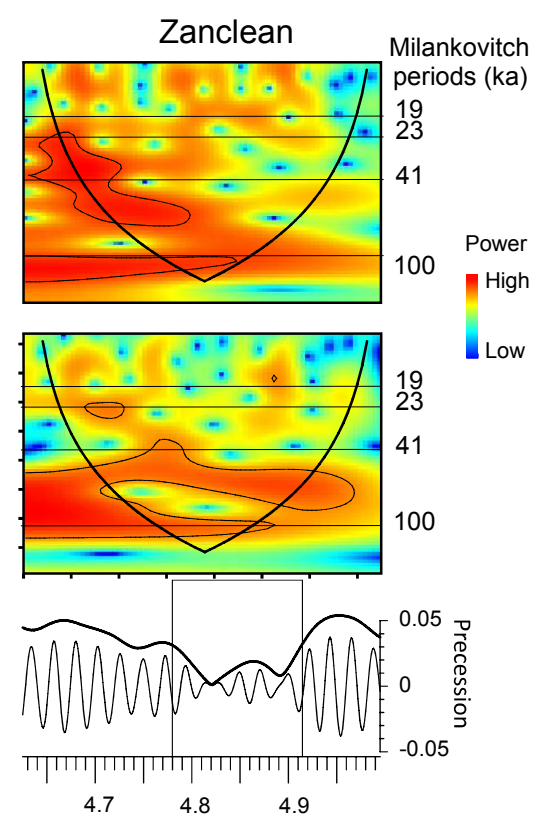

Age (Ma)

Figure 5. Spectral analysis of stable carbon $\left(\delta^{13} \mathrm{C}_{31}\right)$ and hydrogen $\left(\delta \mathrm{D}_{31}\right)$ isotope compositions of the $\mathrm{C}_{31} n$ alkane using a Morlet wavelet for three periods of the Pliocene (4.995-4.625, 3.615-3.310, and 3.270-3.005 Ma). Data are interpolated to $5 \mathrm{kyr}$ steps. Signal power is expressed in colour shadings with the significance level $(p=0.05)$ in black contours. The cone of influence (thick black line) identifies the area of boundary effects. Periodicities per thousand years on the vertical axes ( $\log _{2}$ scale). Horizontal lines denote orbital periodicities of 19 and $23 \mathrm{kyr}$ (precession), $41 \mathrm{kyr}$ (obliquity), and $100 \mathrm{kyr}$. Bottom: eccentricity and precession for the same periods based on Lascar et al. (2004) http://vo.imcce.fr/insola/earth/online/earth/online/. Boxes indicate periods with reduced eccentricity and low precession amplitudes.

During low-eccentricity periods little precession variability is found.

A positive correlation is found between $\delta^{13} \mathrm{C}_{31}$ and $\delta \mathrm{D}_{31}$ for the period between 3.3 and $3.0 \mathrm{Ma}$, corresponding to the mid-Piacenzian Warm Period (mPWP; 3.264-3.025 Ma after Haywood et al., 2013). This is in contrast to the negative correlation found for the last glacial cycle. The earlier Pliocene results do not reveal a significant correlation between stable carbon and hydrogen isotope compositions of the $n-\mathrm{C}_{31}$ alkanes (Table 1).

\section{Discussion}

\subsection{Plant-wax provenance and vegetation sources}

The good correspondence between the dust record of ODP Site 659 (Tiedemann, 1991) and the $n$ alkane concentrations indicate predominance of aeolian transport of plant waxes probably in the form of coatings on dust particles. Pliocene $\delta^{13} \mathrm{C}_{31}$ values display a narrow range around the average of $-25.4 \%$, clearly below the enriched values of up to $-23 \%$ as observed for the last glacial cycle (Fig. 4; Kuechler et al., 2013). The low $\delta^{13} \mathrm{C}_{31}$ variations are attributed to a relatively stable wind system (Tiedemann et al., 1994) and the integration of a large source area. The Pliocene record shows a different pattern than the last glacial cycle, when $\mathrm{C}_{3}$ plant-wax material relatively increased during arid phases, which is attributed to enhanced contributions by the trade winds in combination with no or sparse vegetation cover in the Sahara (Kuechler et al., 2013). This suggests that only small amounts of plant waxes derived from Mediterranean sources because trade winds were weak, in line with the pollen records of ODP Sites 658 (Leroy and Dupont, 1994) and 659 (Vallé et al., 2014). Thus, depleted $\delta^{13} \mathrm{C}_{31}$ values of the Pliocene indicate higher $\mathrm{C}_{3}$ plant coverage at the latitude of the Sahel compared to today suggesting generally more humid conditions. Compared to the last glacial cycle the dominance of $\mathrm{C}_{4}$ plants, estimated up to $90 \%$ (Kuechler et al., 2013), is much less prominent during the Pliocene.

Differences in leaf anatomy, rooting depth and photosynthetic pathway may contribute to the final plant-wax $\delta \mathrm{D}$ signal (Sachse et al., 2012). Overall, $\mathrm{C}_{4}$ grasses are deuteriumdepleted by $\sim 20 \%$ relative to $\mathrm{C}_{3}$ trees (McInerney et al., 2011) and deuterium-enriched by $\sim 20 \%$ o relative to $\mathrm{C}_{3}$ grasses (Smith and Freeman, 2006). However, the absolute variability of $\delta^{13} \mathrm{C}_{31}$ is small $(\sim 2 \%$ ) and would correspond to a vegetation shift between $\mathrm{C}_{3}$ vs. $\mathrm{C}_{4}$ plants of less than $20 \%$, when using the $\delta^{13} \mathrm{C}$ end-members of $-35.2 \%$ o for $\mathrm{C}_{3}$ plants and $-21.7 \%$ for $\mathrm{C}_{4}$ plants (Castañeda et al., 2009). The corresponding difference in hydrogen isotopic fraction- 
ation would be less than $\pm 4 \%$. Compared to the large variability in the plant-wax $\delta \mathrm{D}$ record (between -171 and $-133 \%$ for the $n-\mathrm{C}_{31}$ alkane) such plant-dependent variations are minor. Considering the large uncertainties in the estimation of $\mathrm{C}_{4} / \mathrm{C}_{3}$ plant coverage using stable carbon isotopes, we refrain from applying such a correction.

Pollen records from ODP Sites 658 (Leroy and Dupont, 1994) and 659 (Vallé et al., 2014) indicate that Pliocene subSaharan savannahs have no modern analogue, which harbours the potential for further uncertainties in the plant-wax $\delta \mathrm{D}$ record. Nevertheless, $\delta \mathrm{D}_{\text {wax }}$ studies from offshore of NW Africa covering the African Humid Period ( 15-5 ka) yield a robust humid signal among different records (Niedermeyer et al., 2010; Collins et al., 2013; Kuechler et al., 2013; Tierney et al., 2017), although the vegetation of this African $\mathrm{Hu}-$ mid Period had no modern analogue (Watrin et al., 2009). Watrin et al. emphasize that instead of a homogenous latitudinal shift of vegetation zones as a whole, individual plant species likely have an advantage over others. The robustness of the Holocene $\delta \mathrm{D}_{\text {wax }}$ records implies that this proxy for palaeohydrology is apparently not strongly affected by a "non-analogous" vegetation composition.

\subsection{Choice of age model}

We choose the age model based on stable oxygen isotopes advocated by Clemens (1999) over the original one of Tiedemann et al. (1994), since the former is independent from the dust record and produces a better fit with the global benthic $\delta^{18} \mathrm{O}$ stack (Lisiecki and Raymo, 2005), especially for the Zanclean (Supplement Fig. S1). In general, both age models (dust and $\delta^{18} \mathrm{O}$ ) contain the same orbital frequencies (Supplement). However, the dust age model assumes precession as the main forcing and accordingly, Pliocene dust peaks are tuned to insolation minima. Using the dust age model would introduce age-model-dependent precession variability. The alternative $\delta^{18} \mathrm{O}$-based age model also has a strong precession signal, but only for periods with large precession amplitudes, while obliquity has a stronger impact during times of low precession variability. Moreover, tuning of the dust record would introduce some circular reasoning in our argument as the dust record partly depends on precipitation.

\subsection{Other effects on the sedimentary $\delta \mathrm{D}_{\text {wax }}$ signature}

Aridity may exert a considerable influence on the apparent fractionation $(\varepsilon)$ between plant waxes and meteoric water via evapotranspiration and associated deuterium-enrichment (Polissar and Freeman, 2010; Douglas et al., 2012; Kahmen et al., 2013a, b). It was found that such an effect is less pronounced in lake sediments compared to soils, likely due to the higher potential of lakes to integrate large catchment areas and the small-scale variability of soils related to differences in microclimate and vegetation (Douglas et al., 2012). Niedermeyer et al. (2016) could not detect the effect of evap- otranspiration comparing high-resolution sediment data off West Africa with instrumental records. Our records of the terrigenous fraction in marine sediments also integrate huge catchment areas since large parts of the Sahara and the Sahel can be considered sources of the material of primarily aeolian origin (Tiedemann et al., 1994; Vallé et al., 2014). Moreover, Gao et al. (2014) investigated aerosols from arid and humid subtropical environments and found only minor deviations in $\varepsilon(<10 \%)$, attributed to a possible compensation of isotopic enrichment due to decreasing relative humidity by a shift from trees to grasses in the vegetation. Similar results were found in marine surface sediments forming a transect running west along the central African and southern African coast (Vogts et al., 2016).

The $\delta \mathrm{D}$ record of the $n-\mathrm{C}_{31}$ alkane was adjusted for changes in global ice volume (Tierney and DeMenocal, 2013). The Last Glacial Maximum was scaled to $1 \%$ o (Schrag et al., 2002) in the LR04 global benthic $\delta^{18} \mathrm{O}$ stack (Lisiecki and Raymo, 2005) relative to the present $(0 \%$ ) , and subsequently converted into $\delta \mathrm{D}$ values, using the global meteoric water line. The procedure determined the use of the revised age model (Clemens, 1999), which is based on $\delta^{18} \mathrm{O}$ variability at ODP Site 659 and thus better matches the LR04 stack (Lisiecki and Raymo, 2005). However, the $\delta$ D adjustment for the Pliocene period is almost negligible $(<2 \%)$ and results are not shown.

Finally, plant waxes extracted from modern dust samples offshore of West Africa yielded a radiocarbon age of $650 \pm 150$ years (Eglinton et al., 2002) hinting at residence and transport times of several centuries. Since our research questions concern orbital timescales (and our records have $\mathrm{a} \sim 4 \mathrm{kyr}$ resolution), intermediate storage on the continent and mixing of plant waxes are considered to have a negligible effect on our interpretations.

\subsection{Aridity and humidity in Pliocene West Africa}

In contrast to the stable carbon record, which shows much less variability for the Pliocene than in the last glacial cycle, the fluctuations in the deuterium record are of the same amplitude, indicating large variations between arid and humid periods in West Africa occurred long before the intensification of Northern Hemisphere glaciations. Correspondence between the $\delta \mathrm{D}_{31}$ and the dust record of ODP Site 659 support previous conclusions concerning the generation of dust during arid periods (Tiedemann et al., 1994) and the use of $\delta \mathrm{D}_{31}$ as humidity proxy. With it we present the first proxy record of West African humidity and precipitation during the Pliocene. This record is also important because river discharge and run-off from northern Africa (including the eastern parts of West Africa) is crucial for the development of Mediterranean sapropel layers. Almost all recognized sapropels can be correlated with maxima in West African humidity (Fig. 6; $\delta \mathrm{D}_{31}$ minima). In general, our findings highlight the influence of the West African monsoon for 
(a)

(b)

(c)

(d)

(e) $\begin{aligned} & \text { Increased } \\ & \text { monsoon }\end{aligned}$

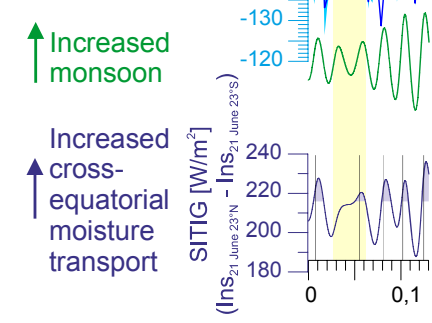

(i)

Monsoon
front
northwards

个etter

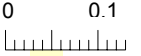
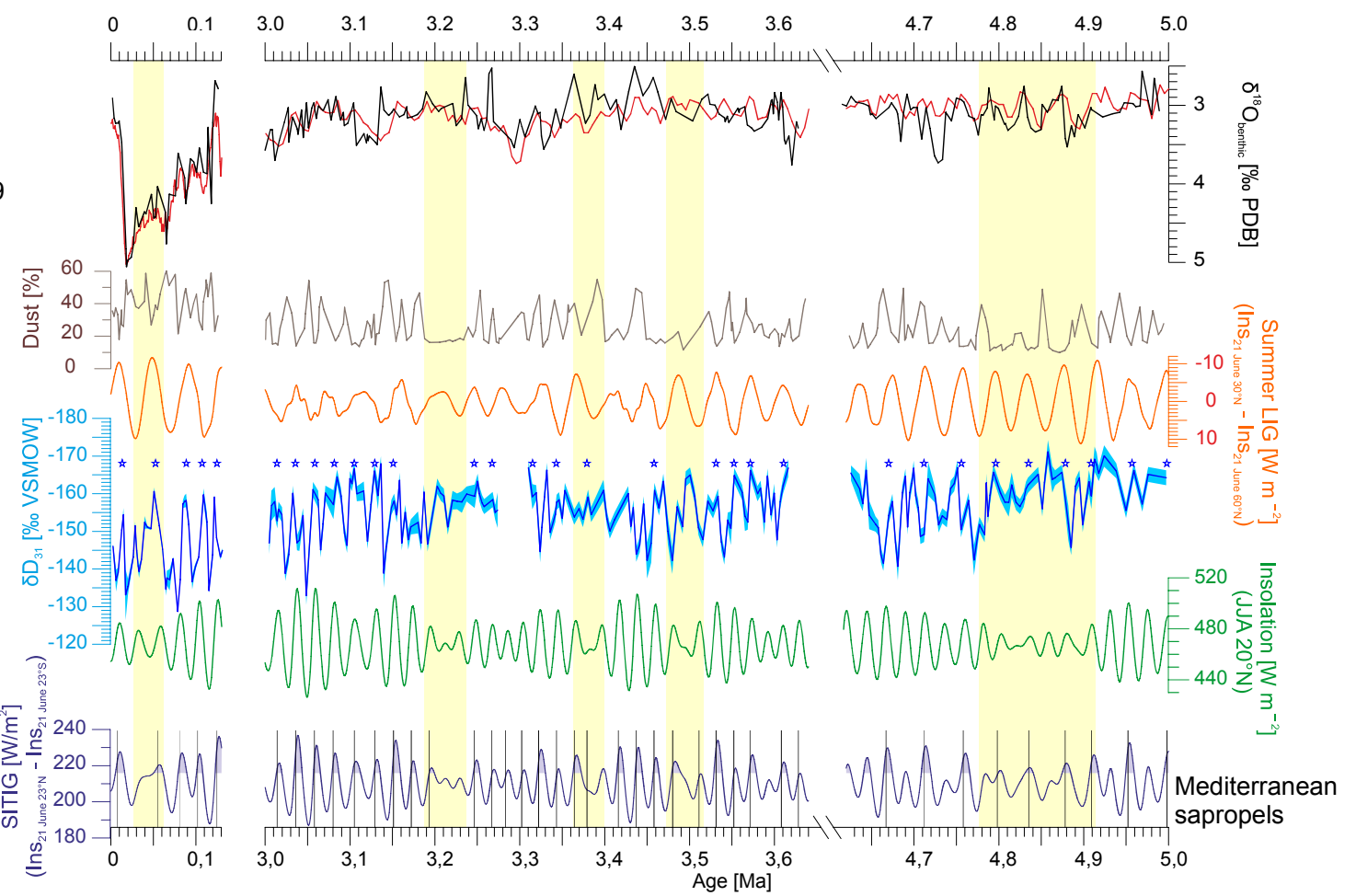

Figure 6. Multiple isolation forcings. (a-f) Stable oxygen isotopes of benthic foraminifers $\left(\delta^{18} \mathrm{O}_{\text {benthic }}\right)$ from ODP Site 659 (Tiedemann et al., 1994) compared to the global stack LR04 (Lisiecki and Raymo, 2005) in per mil vs. Pee Dee Belemnite (PDB); dust percentages after (Tiedemann, 1991); summer latitudinal insolation gradient (LIG) calculated from the 21 June insolation at $30^{\circ} \mathrm{N}$ minus that of $60^{\circ} \mathrm{N}$; stable hydrogen isotope composition $\delta \mathrm{D}_{31}$ in per mil vs. Vienna Standard Mean Ocean Water (VSMOW) for the last glacial cycle after Kuechler et al. (2013) and for the Pliocene (this study) - stars indicate $\delta \mathrm{D}_{31}$ minima associated with Mediterranean sapropels; summer insolation (June, July, August) at $20^{\circ} \mathrm{N}$; cross-equatorial summer inter-tropical insolation gradient (SITIG) calculated from the 21 June insolation at $23^{\circ} \mathrm{N}$ minus that of $23^{\circ} \mathrm{S}$ and occurrence of Mediterranean sapropels (Emeis et al., 2000). Insolation values from http://vo.imcce.fr/insola/ earth/online/earth/online/ (Laskar et al., 2004). Yellow shading denotes periods with low precession variability.

Mediterranean sapropel formation, and corroborate a recurrent greening of the Sahara, which might have intermittently allowed hominin migration through otherwise hostile territory (Larrasoaña et al., 2013).

Precipitation in West and northern Africa depends on the West African monsoon mainly varying with low-latitude summer insolation, which is dominated by 19 and $23 \mathrm{kyr}$ periodicities of the precession cycle (e.g. Kutzbach, 1981; see also Introduction). However, variations in low-latitude insolation cannot explain the entire variability in the $\delta \mathrm{D}_{31}$ and dust records. For instance, four dust percentage maxima between 4.91 and $4.77 \mathrm{Ma}$ correspond to four obliquity minima. Examples of humid periods (strongly depleted $\delta \mathrm{D}_{31}$ ) during insolation minima were found shortly before $4.90 \mathrm{Ma}$, centred at 4.79 and $3.50 \mathrm{Ma}$, or just after $3.20 \mathrm{Ma}$. Conversely, examples of arid periods (less depleted $\delta \mathrm{D}_{31}$ ) during insolation maxima are centred at 4.88, 4.78, 3.48, and $337 \mathrm{Ma}$ and just before $3.20 \mathrm{Ma}$ (Fig. 6). Moreover, spectral analysis of both Pliocene (Fig. 5) and Pleistocene (last glacial cycle; Fig. 7) series indicate a more complicated pattern with additional periodicities unrelated to precession. These periods, in which humidity changes do not follow low-latitude insolation, might be linked to obliquity. Shifts in variability already occurred prior to the intensification of the Northern Hemisphere glaciation at the beginning of the Pleistocene $(2.58 \mathrm{Ma})$, but are most prominent during the last glacial cycle.

The mechanistic basis for the obliquity signal in lowlatitude climate records is a matter of debate. Modelling studies show contrasting results, both including (Tuenter et al., 2003; Weber and Tuenter, 2011) and excluding (Bosmans et al., 2015a; Rachmayani et al., 2016) an influence of the high latitudes. On the one hand, obliquity in the tropics is attributed to higher moisture transport from mid/high latitudes (Tuenter et al., 2003) or varying ice sheets and greenhouse gases (Weber and Tuenter, 2011) that influence the monsoon intensity and timing. On the other hand, recent modelling studies revealed an increase in monsoonal rainfall due to a stronger atmospheric pressure contrast between the western African continent (low pressure) and the South Atlantic (high 


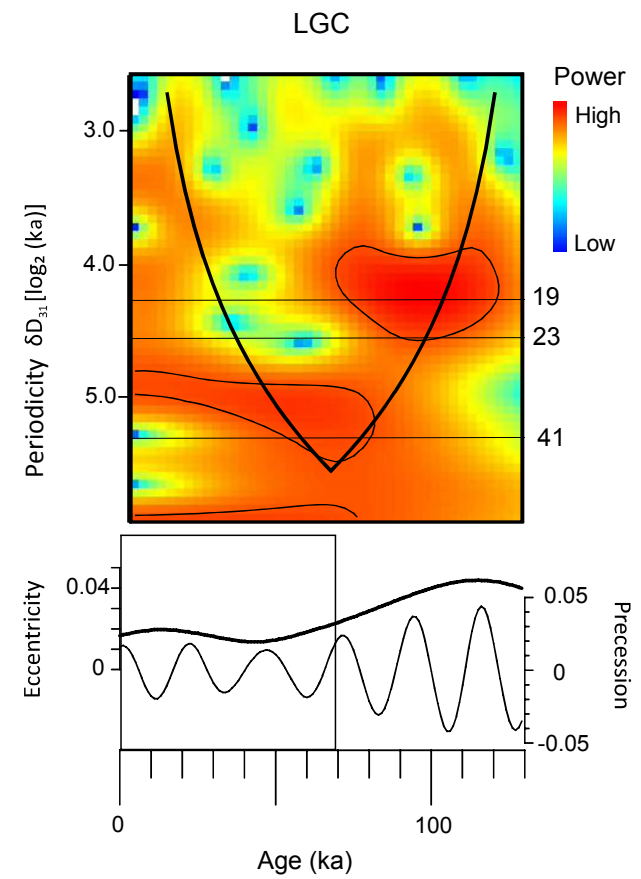

Figure 7. Spectral analysis of hydrogen $\left(\delta_{31}\right)$ isotope compositions of the $\mathrm{C}_{31} n$ alkane (from Kuechler et al., 2013) using a Morlet wavelet for the last glacial cycle (LGC). Data are interpolated to $3 \mathrm{kyr}$ steps. Signal power is expressed in colour shadings with the significance level $(p=0.05)$ in black contours. The cone of influence (thick black line) identifies the area of boundary effects. Periodicities per thousand years on the vertical axes ( $\log _{2}$ scale). Horizontal lines denote orbital periodicities of 19 and $23 \mathrm{kyr}$ (precession), and $41 \mathrm{kyr}$ (obliquity). Bottom: eccentricity and precession for the same period. The box indicates the period with reduced eccentricity and low precession amplitudes.

pressure) under conditions of low precession (i.e. maximum local insolation) and high obliquity. Based on this, the interhemispheric (or cross-equatorial) insolation gradient (summer inter-tropical insolation gradient) at lower latitudes was suggested to drive winds and associated moisture transport (Bosmans et al., 2015a, b). In general, insolation gradients shape the climate system by differential heating and thus determine spatial temperature patterns, which ultimately steer atmospheric pressure gradients (Nicholson, 2009).

On orbital timescales, the periodicity of glacialinterglacial cycles with the high-to-low-latitude contrast in insolation (i.e. latitudinal insolation gradient) forces moisture fluxes poleward via strong gradients, thus triggering ice sheet growth (Raymo and Nisancioglu, 2003). In this context, most studies focus on high latitudes, and studies considering a latitudinal gradient forcing of tropical monsoon systems are limited to the last glacial cycle (e.g. Davis and Brewer, 2009). However, summer weakening of the latitudinal gradient when obliquity is strong would lead to a northward shift of the tropical monsoon front (Davis and Brewer, 2009).
This was recently supported by another climate model, indicating a tight link between the gradient-controlled midlatitude eddy circulation (driving the heat and moisture transport from low to high latitudes) and the poleward boundary of the tropical rain belt (Mantsis et al., 2014). Thus, a northward shift of the tropical monsoon front is related to increased mid-latitude eddy circulation during summer when the latitudinal temperature gradient linked to the summer latitudinal insolation gradient (dominated by obliquity) is large. For West Africa the strongest monsoonal influence would thus be expected during summer when the latitudinal gradient is weak, shifting the tropical rain belt northward, instead of being purely triggered by local insolation. For the Pliocene, both proxy data and model results confirm reduced meridional and zonal temperature gradients when the tropical monsoon was enhanced (Dowsett et al., 2013; Haywood et al., 2013). Solely low-latitude insolation forcing cannot explain the variations in the $\delta \mathrm{D}_{31}$ and dust records.

\subsection{Towards a more comprehensive understanding of the drivers of the West African monsoon}

Based on our results from the Pliocene and comparison with the last glacial cycle we propose a modified gradient forcing mechanism. Wavelet analyses show repeated shifts in the periodicity of the $\delta \mathrm{D}_{31}$ records from the obliquity to the precession band and vice versa, depending on the amplitudes in precession and obliquity (Figs. 5 and 7). We infer a consistent pattern with generally two modes: during periods with strong precession cycles (i.e. high eccentricity), the influence of summer LIG on monsoon variability is superimposed by changes in local insolation. In contrast, during weak precession cycles, especially those of the last glacial cycle, summer LIG forms the primary forcing of the West African monsoon and its influence on the northward distribution of atmospheric moisture plays the decisive role in the West African climate. This is also supported by climate models, which show a strong dependency of the obliquity-induced precipitation response to precession, but not vice versa (Tuenter et al., 2003). The indication for LIG forcing during weak precession cycles of the Pliocene is less pronounced than during the Late Pleistocene suggesting that the obliquity forcing of the summer LIG is reinforced by the intensification of the Northern Hemisphere glaciation. LIG-induced climate shifts during the last glacial cycle are more severe than during the Pliocene due to increased ice-albedo feedbacks (Raymo and Nisancioglu, 2003). In addition, the duration of humid-arid periods seems to increase in the course of the last glacial cycle, reflecting the shift from one dominant forcing to another, i.e. from precession to obliquity. These findings caution against a too simplified view on orbital forcing mechanisms of the (tropical) hydrologic cycle and hence related records. 


\section{Conclusions}

Our new West African monsoon records suggest that orbital forcing is indeed the major control of monsoon variability, but indicate that changes in local summer insolation are insufficient to explain the full degree of hydrologic variations. We infer a hybrid insolation forcing with two modes, depending on the strength of the precession cycle: during high eccentricity (large precession fluctuations), the main driver is the precession-controlled local summer insolation, but during low eccentricity, the obliquity-controlled summer latitudinal insolation gradient becomes more important. After the Pliocene, the subsequent intensification of the Northern Hemisphere glaciations would have reinforced the obliquity component in West African monsoon variability via the summer insolation gradient.

Data availability. Data sets are stored online at PANGAEA (https://doi.org/10.1594/PANGAEA.875694; Küchler et al., 2017).

\section{The Supplement related to this article is available online at https://doi.org/10.5194/cp-14-73-2018-supplement.}

Author contributions. ES designed the research project. Laboratory work was carried out by RRK and ES, LMD, RRK and ES contributed to interpretation and discussion of the results. RRK prepared the manuscript with contributions from all co-authors.

Competing interests. The authors declare that they have no conflict of interest.

Acknowledgements. We thank Britta Beckmann, Wolfgang Bevern, Thomas Evans and Meral Yavuz for assistance in the laboratory, Steven Clemens for providing the data of the revised age model, and Ralf Tiedemann for comments and discussion. This study was financially supported by the Deutsche Forschungsgemeinschaft (DFG) through the priority programme 527 "IODP/ODP" (Sche903/11) with additional support by the Research Center/Excellence Cluster "The Ocean in the Earth System" at MARUM - Center for Marine Environmental Sciences, University of Bremen. Rony Kuechler acknowledges further support by GLOMAR - Bremen International Graduate School for Marine Sciences.

The article processing charges for this open-access publication were covered by the University of Bremen.

Edited by: Luc Beaufort

Reviewed by: two anonymous referees

\section{References}

Bosmans, J. H. C., Drijfhout, S. S., Tuenter, E., Hilgen, F. J., and Lourens, L.: Response of the North African summer monsoon to precession and obliquity forcing in the EC-Earth GCM, Clim. Dynam., 44, 279-297, https://doi.org/10.1007/s00382014-2260-z, 2015a.

Bosmans, J. H. C., Hilgen, F. J., Tuenter, E., and Lourens, L. J.: Obliquity forcing of low-latitude climate, Clim. Past, 11, 13351346, https://doi.org/10.5194/cp-11-1335-2015, 2015 b.

Brohan, P., Kenndey, J. J., Harris, I., Tett, S. F. B., and Jones, P. D.: Uncertainty estimates in regional and global observed temperature changes: a new data set from 1850, J. Geophys. Res., 111, D12106, https://doi.org/10.1029/2005JD006548, 2006.

Castañeda, I. S., Mulitza, S., Schefuß, E., Lopes dos Santos, R. A., Sinninghe Damsté, J. S., and Schouten, S.: Wet phases in the Sahara/Sahel region and human migration patterns in North Africa, P. Natl. Acad. Sci. USA, 106, 20159-20163, 2009.

Clemens, S.: An astronomical tuning strategy for Pliocene sections: implications for global-scale correlation and phase relationships, Philos. T. R. Soc. Lond. A, 357, 1949-1973, 1999.

Colleoni, F., Masina, S., Negri, A., and Marzocchi, A.: PlioPleistocene high-low latitude climate interplay: a Mediterranean point of view, Earth Planet. Sc. Lett., 319-320, 35-44, 2012.

Collins, J. A., Schefuß, E., Mulitza, S., Prange, M., Werner, M., Tharammal, T., Paul, A., and Wefer, G.: Estimating the hydrogen isotopic composition of past precipitation using leaf-waxes from western Africa, Quaternary Sci. Rev., 65, 88-101, 2013.

Dansgaard, W.: Stable isotopes in precipitation, Tellus, 116, 436468, 1964

Davis, B. A. S. and Brewer, S.: Orbital forcing and role of the latitudinal insolation/temperature gradient, Clim. Dynam., 32, 143$165,2009$.

Davis, B. A. S. and Brewer, S.: A unified approach to orbital, solar, and lunar forcing based on the Earth's latitudinal insolation/temperature gradient, Quaternary Sci. Rev., 30, 1861-1874, 2011.

DeMenocal, P.: Plio-Pleistocene African climate, Science, 270, 53$59,1995$.

Douglas, P. M. J., Pagani, M., Brenner, M., Hodell, D. A., and Curtis, J. H.: Aridity and vegetation composition are important determinants of leaf-wax $\delta \mathrm{D}$ values in southeastern Mexico and Central America, Geochim. Cosmochim. Ac., 97, 24-45, 2012.

Dowsett, H. J., Foley, K. M., Stoll, D. K., Chandler, M. A., Sohl, L., Bentsen, M., Otto-Bliesner, B. L., Bragg, F., Chan, W.-L., Contoux, C., Dolan, A. M., Haywood, A. M., Jonas, J. A., Jost, A., Kamae, Y., Lohmann, G., Lunt, D. J., Nisancioglu, K. H., AbeOuchi, A., Ramstein, G., Riesselman, C. R., Robinson, M. M., Rosenbloom, N. A., Salzmann, U., Stepanek, C., Strother, S. L., Ueda, H., Yan, Q., and Zhang, Z.: Sea surface temperature of the mid-Piacenzian Ocean: a data-model comparison, Sci. Rep.-UK, 3, 1-8, 2013.

Dupont, L. M., Beug, H.-J., Stalling, H., and Tiedemann, R.: 6. First palynological results from Site 658 at $21^{\circ} \mathrm{N}$ off Northwest Africa: pollen as climate indicators, in: Proceedings of the Ocean Drilling Program, Scientific Results, edited by: Ruddiman, W. F., Sarnthein, M., and shipboard party, Volume 108, Ocean Drilling Program, College Station, TX, 93-111, 1989. 
Eglinton, G. and Hamilton, R. J.: Leaf epicuticular waxes, Science, 156, 1322-1335, 1967.

Eglinton, T. I., Eglinton, G., Dupont, L., Sholkovitz, E. R., Montluçon, D., and Reddy, C. M.: Composition, age, and provenance of organic matter in NW African dust over the Atlantic Ocean, Geochem. Geophy. Geosy., 3, 1-27, https://doi.org/10.1029/2001GC000269, 2002.

Emeis, K.-C., Sakamoto, T., Wehausen, R., and Brumsack, H.-J.: The sapropel record of the eastern Mediterranean Sea - results of Ocean Drilling Program Leg 160, Palaeogeogr. Palaeocl., 158, 371-395, 2000.

Gao, L., Zheng, M., Fraser, M., and Huang, Y.: Comparable hydrogen isotopic fractionation of plant leaf wax $n$ alkanoic acids in arid and humid subtropical ecosystems, Geochem. Geophy. Geosy., 15, 361-373, 2014.

Hammer, Ø., Harper, D. A. T., and Ryan, P. D.: PAST: paleontological statistical software package for education and data analysis, Palaeontol. Electron., 4, 1-9, 2001.

Haywood, A. M., Hill, D. J., Dolan, A. M., Otto-Bliesner, B. L., Bragg, F., Chan, W.-L., Chandler, M. A., Contoux, C., Dowsett, H. J., Jost, A., Kamae, Y., Lohmann, G., Lunt, D. J., Abe-Ouchi, A., Pickering, S. J., Ramstein, G., Rosenbloom, N. A., Salzmann, U., Sohl, L., Stepanek, C., Ueda, H., Yan, Q., and Zhang, Z.: Large-scale features of Pliocene climate: results from the Pliocene Model Intercomparison Project, Clim. Past, 9, 191-209, https://doi.org/10.5194/cp-9-191-2013, 2013.

Held, I. M. and Soden, B. J.: Water vapor feedback and global warming, Annu. Rev. Env. Resour., 25, 441-475, 2000.

IAEA/WMO: Global Network of Isotopes in Precipitation. The GNIP Database, available at: http://www.iaea.org/water, last access: 27 November 2014.

Kahmen, A., Schefuß, E., and Sachse, D.: Leaf water deuterium enrichment shapes leaf wax $n$ alkane $\delta \mathrm{D}$ values of angiosperm plants I: Experimental evidence and mechanistic insights, Geochim. Cosmochim. Ac., 111, 39-49, 2013a.

Kahmen, A., Hoffmann, B., Schefuß, E., Arndt, S. K., Cernusak, L. A., West, J. B., and Sachse, D.: Leaf water deuterium enrichment shapes leaf wax $n$ alkane $\delta \mathrm{D}$ values of angiosperm plants II: Observational evidence and global implications, Geochim. Cosmochim. Ac., 111, 50-63, 2013b.

Kuechler, R. R., Schefuß, E., Beckmann, B., Dupont, L., and Wefer, G.: NW African hydrology and vegetation during the Last Glacial cycle reflected in plant-wax-specific hydrogen and carbon isotopes, Quaternary Sci. Rev., 82, 56-67, 2013.

Küchler, R. R., Dupont, L. M., and Schefuß, E.: Pliocene stable carbon and hydrogen isotopes of plant wax of ODP Site 108-659, PANGAEA, , 2017.

Kutzbach, J. E.: Monsoon climate of the Early Holocene: climate experiment with the Earth's orbital parameters for 9000 years ago, Science, 214, 59-61, 1981.

Larrasoaña, J. C., Roberts, A. P., and Rohling, E. J.: Dynamics of green Sahara periods and their role in hominin evolution, PLOS ONE, 8, e76514, https://doi.org/10.1371/journal.pone.0076514, 2013.

Laskar, J.: The chaotic motion of the solar system: a numerical estimate of the size of the chaotic zones, Icarus, 88, 266-291, 1990.

Laskar, J., Robutel, P., Joutel, F., Gastineau, M., Correia, A. C. M., and Levrard, B.: A long term numerical solution for the insola- tion quantities of the Earth, Astron. Astrophys., 428, 261-285, 2004.

Leroy, S. and Dupont, L.: Development of vegetation and continental aridity in northwestern Africa during the Late Pliocene: the pollen record of ODP Site 658, Palaeogeogr. Palaeocl., 109, 295-316, 1994.

Leuschner, D. C. and Sirocko, F.: Orbital insolation forcing of the Indian Monsoon - a motor for global climate changes?, Palaeogeogr. Palaeocl., 197, 83-95, 2003.

Lindzen, R. S.: Dynamics in Atmospheric Physics, Cambridge University Press, New York, 1990.

Lindzen, R. S.: Climate dynamics and global change, Annu. Rev. Fluid Mech., 26, 353-378, 1994.

Lisiecki, L. E. and Raymo, M. E.: A Pliocene-Pleistocene stack of 57 globally distributed benthic $\delta^{18} \mathrm{O}$ records, Paleoceanography, 20, PA1003, https://doi.org/10.1029/2004PA001071, 2005.

Lourens, L. J., Antonarakou, A., Hilgen, F. J., Van Hoof, A. A. M., Vergnaud-Grazzini, C., and Zachariasse, W. J.: Evaluation of the Plio-Pleistocene astronomical timescale, Paleoceanography, 11, 391-413, 1996.

Mantsis, D. F., Lintner, B. R., Broccoli, A. J., and Erb, M. P.: The response of large-scale circulation to obliquity-induced changes in meridional heating gradients, J. Climate, 27, 5504-5516, 2014.

McInerney, F. A., Helliker, B. R., and Freeman, K. H.: Hydrogen isotope ratios of leaf wax $n$ alkanes in grasses are insensitive to transpiration: Geochim. Cosmochim. Ac., 75, 541-554, 2011.

Mohtadi, M., Prange, M., and Steinke, S.: Palaeoclimatic insights into forcing and response of monsoon rainfall, Nature, 533, 191199, 2016.

Nicholson, S. E.: Rainfall and atmospheric circulation during drought periods and wetter years in Africa, Mon. Weather Rev., 109, 2191-2208, 1981.

Nicholson, S. E.: The nature of rainfall variability over Africa on time scales of decades to millennia, Global Planet. Change, 26, 137-158, 2000.

Nicholson, S. E.: A revised picture of the structure of the "monsoon" and land ITCZ over West Africa, Clim. Dynam., 32, 11551171, 2009.

Nicholson, S. E., Grist, J. P.: The seasonal evolution of the atmospheric circulation over West Africa and equatorial Africa, J. Climate, 16, 1013-1030, 2003.

Niedermeyer, E. M., Schefuß, E., Sessions, A. L., Mulitza, S., Mollenhauer, G., Schulz, M., and Wefer, G.: Orbital- and millennialscale changes in the hydrologic cycle and vegetation in the western African Sahel: insights from individual plant wax $\delta \mathrm{D}$ and $\delta^{13}$ C, Quaternary Sci. Rev., 29, 2996-3005, 2010.

Niedermeyer, E. M., Forrest, M., Becjmann, B., Sessions, A. L., Mulch, A., and Schefuß, E.: The stable hydrogen isotopic composition of sedimentary plant waxes as quantitative proxy for rainfall in the West African Sahel, Geochim. Cosmochim. Ac., 184, 55-70, 2016.

Peixoto, J. P. and Oort, A. H.: Physics of Climate, American Institute of Physics, New York, 1992.

Polissar, P. J. and Freeman, K. H.: Effects of aridity and vegetation on plant-wax $\delta \mathrm{D}$ in modern lake sediments, Geochim. Cosmochim. Ac., 74, 5785-5797, 2010.

Rachmayani, R., Prange, M., and Schulz, M.: Intra-interglacial climate variability: model simulations of Marine Isotope 
Stages 1, 5, 11, 13, and 15, Clim. Past, 12, 677-695, https://doi.org/10.5194/cp-12-677-2016, 2016.

Raymo, M. E. and Nisancioglu, K.: The 41 kyr world: Milankovich's other unsolved mystery, Paleoceanography, 18, 1011, https://doi.org/10.1029/2002PA000791, 2003.

Reichart, G. J.: Late Quaternary variability of the Arabian Sea monsoon and oxygen minimum zone, Geologica Ultraiectina, Thesis University of Utrecht, 154, 1-174, 1997.

Risi, C., Bony, S., Vimeux, F., Descroix, L., Ibrahim, B., Lebreton, E., Mamadou, I., and Sultan, B.: What controls the isotopic composition of the African monsoon precipitation? Insights from event-based precipitation collected during the 2006 AMMA field campaign, Geophys. Res. Lett., 35, L24808, https://doi.org/10.1029/2008GL035920, 2008.

Rossignol-Strick, M.: African monsoons, an immediate climate response to orbital insolation, Nature, 304, 46-49, 1983.

Rozanski, K., Araguás-Araguás, L., and Gonfiantini, R.: Isotopic patterns in modern global precipitation, in: Climate Change in Continental Isotopic Records, edited by: Swart, P. K., Lohmann, K. C., McKenzie, J., and Savin, S., AGU Geophysical Monograph, AGU, Washington, D.C. vol. 78, 1-36, 1993.

Ruddiman, W. F., Sarnthein, M., and shipboard party: Initial Reports of the DSDP/ODP, 108A, US Governmental Printing Office, Washington, 657-668, 1987.

Sachse, D., Billaut, I., Bowen, G. J., Chikaraishi, Y., Dawson, T. E., Feakins, S. J., Freeman, K. H., Magill, C. R., McInerney, F. A., van der Meer, M. T. J., Polissar, P., Robins, R. J., Sachs, J. P., Schmidt, H.-L., Sessions, A. L., White, J. W. C., West, J. B., and Kahmen, A.: Molecular paleohydrology: interpreting the hydrogen-isotopic composition of lipid biomarkers from photosynthesizing organisms, Annu. Rev. Earth Pl. Sc., 40, 221-249, 2012.

Salzmann, U., Dolan, A. M., Haywood, A. M., Chan, W.-L., Voss, J., Hill, D. J., Abe-Ouchi, A., Otto-Bliesner, B. L., Bragg, F., Chandler, M. A., Contoux, C., Dowsett, H. J., Jost, A., Kamae, Y., Lohmann, G., Lunt, D. J., Pickering, S. J., Pound, M. J., Ramstein, G., Rosenbloom, N. A., Sohl, L., Stepanek, C., Ueda, H., and Zhang, Z.: Challenges in quantifying Pliocene terrestrial warming revealed by data-model discord, Nat. Clim. Change, 3, 969-974, https://doi.org/10.1038/nclimate2008, 2013.

Schrag, D. P., Adkins, J. F., McIntyre, K., Alexander, J. L., Hodell, D. A., Charles, C. D., and McManus, J. F.: The oxygen isotopic composition of seawater during the Last Glacial Maximum, Quaternary Sci. Rev., 21, 331-342, 2002.
Smith, F. A. and Freeman, K. H.: Influence of physiology and climate on $\delta \mathrm{D}$ of leaf wax $n$ alkanes from $\mathrm{C}_{3}$ and $\mathrm{C}_{4}$ grasses, Geochim. Cosmochim. Ac., 70, 1172-1187, 2006.

Tiedemann, R.: Acht Millionen Jahre Klimageschichte von Nordwest Afrika und Paläo-Ozeanographie des angrenzenden Atlantiks: hochauflösende Zeitreihen von ODP-Sites 658-661, Thesis University Kiel, 1991.

Tiedemann, R., Sarnthein, M., and Shackleton, N. J.: Astronomic timescale for the Pliocene Atlantic $\delta^{18} \mathrm{O}$ and dust flux records of Ocean Drilling Program site 659, Paleoceanography, 9, 619-638, 1994.

Tierney, J. E. and DeMenocal, B.: Abrupt shifts in Horn of Africa hydroclimate since the Last Glacial Maximum, Science, 342, 843-846, 2013.

Tierney, J. E., Pausata, F. S. R., and DeMenocal, P. B.: Rainfall regimes of the Green Sahara, Science Advances, 3, e1601503, https://doi.org/10.1126/sciadv.1601503, 2017.

Torrence, C. and Compo, G. P.: A practical guide to wavelet analysis, B. Am. Meteorol. Soc., 79, 61-78, 1998.

Tuenter, E., Weber, S. L., Hilgen, F. J., and Lourens, L.: The response of the African summer monsoon to remote and local forcing due to precession and obliquity, Global Planet. Change, 36, 219-235, 2003.

Vallé, F., Dupont, L. M., Leroy, S. A. G., Schefuß, E., and Wefer, G.: Pliocene environmental change in West Africa and the onset of strong NE trade winds (ODP Sites 659 and 658), Palaeogeogr. Palaeocl., 414, 403-414, 2014.

Vogts, A., Moossen, H., Rommerskirchen, F., and Rullkötter, J.: Distribution patterns and stable carbon isotopic composition of alkanes and alkan-1-ols from plant waxes of African rain forest and savanna $\mathrm{C}_{3}$ species, Org. Geochem., 40, 1037-1054, 2009.

Vogts, A., Badewien, T., Rullkötter, J., and Schefuß, E.: Nearconstant apparent hydrogen isotope fractionation between leaf wax $n$-alkanes and precipitation in tropical regions: evidence from a marine sediment transect off SW Africa, Org. Geochem., 96, 18-27, 2016.

Watrin, J., Lézine, A.-M., Hély, C., and APD-Contributors: Plant migration and plant communities at the time of the "green Sahara”, CR Geosci., 341, 656-670, 2009.

Weber, S. L. and Tuenter, E.: The impact of varying ice sheets and greenhouse gases on the intensity and timing of boreal summer monsoons, Quaternary Sci. Rev., 30, 469-479, 2011.

White, F.: The Vegetation of Africa, Natural Resources Research 20, UNESCO, Paris, 1983. 